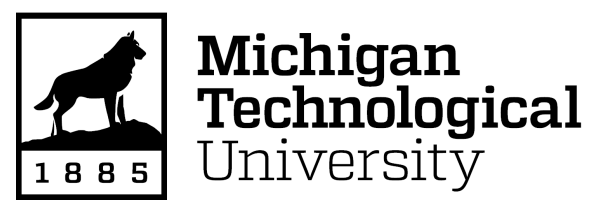

Michigan Technological University Digital Commons @ Michigan Tech

$10-2016$

\title{
Assisted tree migration in North America: Policy legacies, enhanced forest policy integration, and climate change adaptation
}

\author{
Adam Wellstead \\ Michigan Technological University \\ Michael Howlett \\ Simon Fraser University
}

Follow this and additional works at: https://digitalcommons.mtu.edu/social-sciences-fp

Part of the Agricultural and Resource Economics Commons, Agricultural Economics Commons, and the Forest Management Commons

\section{Recommended Citation}

Wellstead, A., \& Howlett, M. (2016). Assisted tree migration in North America: Policy legacies, enhanced forest policy integration, and climate change adaptation. Scandinavian Journal of Forest Research, 1-24. http://dx.doi.org/10.1080/02827581.2016.1249022

Retrieved from: https://digitalcommons.mtu.edu/social-sciences-fp/2

Follow this and additional works at: https://digitalcommons.mtu.edu/social-sciences-fp

Part of the Agricultural and Resource Economics Commons, Agricultural Economics Commons, and the Forest Management Commons 


\section{Assisted Tree Migration in North America: Policy Legacies, Enhanced Forest Policy Integration, and Climate Change Adaptation}

\section{Adam Wellstead \& Michael Howlett}

To cite this article: Adam Wellstead \& Michael Howlett (2016): Assisted Tree Migration in North America: Policy Legacies, Enhanced Forest Policy Integration, and Climate Change Adaptation, Scandinavian Journal of Forest Research, DOI: 10.1080/02827581.2016.1249022

To link to this article: http://dx.doi.org/10.1080/02827581.2016.1249022

Accepted author version posted online: 14 Oct 2016.

Submit your article to this journal $\square$

Џ Article views: 14

Q View related articles $\sqsubset$

View Crossmark data $\nearrow$ 
Publisher: Taylor \& Francis \& Informa UK Limited, trading as Taylor \& Francis Group Journal: Scandinavian Journal of Forest Research

DOI: $10.1080 / 02827581.2016 .1249022$

Assisted Tree Migration in North America:

Policy Legacies, Enhanced Forest Policy Integration, and Climate Change Adaptation

Adam Wellstead

Michigan Technological University

Houghton, Michigan

USA

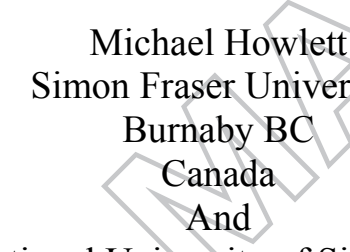

National University of Singapore

Singapore

Prepared for the Scandinavian Journal of Forest Research

Final Revised Version 2.0

October 9, 2016 


\begin{abstract}
The weight of much expert forest management opinion is that issues such as climate change can be effectively addressed only if forest policy-making moves from a purely sectoral focus and undergoes a shift to a more integrated multi-issue, multi-sector policy-making process. This is because credible adaptation policies in the sector require greatly enhanced multi-sectoral policy integration if they are to succeed. But this requirement may be beyond the capacity of many countries to deliver. This article explores the integration challenges faced by forest policymaking in Canada and the United States and uses the case of Assisted Tree Migration (ATM) to probe the reasons for the failure of institutions in both countries to develop and manage better vertical and horizontal integration in a climate change related forest policy area. The article emphasizes the importance of previous rounds of policy-making or 'policy legacies' which serve to constrain contemporary policy options. It argues that due to presence of many such legacies, forest policy development will continue to feature incremental adjustments through policy layering and policy drift, processes which limit the prospects for greater integration and better climate change adaptation in this sector.
\end{abstract}

\title{
Introduction
}

In 2010, an IUFRO expert panel on forest governance addressed the issue of improving forest policy integration, a subject which has been the holy grail of many commentators, critics and proponents of existing policies in the sector for some time. The panel suggested that in the era of global problems such as climate change the future of forest policy required policy-making to shift from an emphasis on sectoral regimes oriented towards 'siloed' problems and issues specific to the industry to new cross-sectoral regimes with a broader remit, linked to a variety of forest and non-forest specific issues involved in climate change adaptation (Rayner and Buck 2010). At around the same time, the FAO also called for greater moves towards adaptive forest management, which it felt was essential to address arising challenges and reduce climate change vulnerabilities (FA0 2010).

These calls for enhanced integration continue to be made within the forest sector. In Canada and the United States, for example, climate change impacts already being felt on-theground have led to increasing calls for new forest policies with a focus on integration and adaptation. Prompted in part by the devastating mountain pine beetle outbreak in British Columbia and Alberta, for example, the Canadian Council of Forest Ministers (CCFM) identified climate change adaptation and improved horizontal and vertical policy integration as a priority 
and after 2008 began taking steps towards developing a national vulnerability assessment and strategy expected to promote this development. In the United States, property loss and deaths from wild fires around the same time also led to climate change adaptation efforts by individual states (e.g., Alaska and California) with the same end of enhanced integration in mind. To further this goal, the US Forest Service developed a "National Road Map for Responding to Climate Change" that proposed to involve the engagement of a wide variety of other stakeholder and government organizations in an integrative process of the type advocated by the IUFRO expert panel.

New policies are expected to integrate climate change adaptation efforts across a number of land and resource-related areas, from energy to mining, water use, biodiversity and conservation, and forestry, in order to offset the effects of climate change and better protect the extensive forests of the continent and the livelihoods of the communities that depend upon them. This is true both "horizontally" across sectors as well as "vertically"; that is, at the subnational level where provincial and state governments have dedicated significant resources to forest-based climate change vulnerability assessments and adaptation frameworks. However proposals to develop and expand the number and types of policies to be integrated into forest policy such as the two listed above, unfortunately, are long on analysis and short on the specifics about how this might be accomplished.

In what follows, we use an historical institutional approach in order to trace the development of a relatively simple yet critical component of forest adaptation policies in both countries, assisted tree migration or ATM. ATM is one of a number of specific adaptation measures that focus on species level management considerations such as the development of pestresistant or drought-tolerant varieties, the use of stocks from a range of provenances, and the planting of genotypes of species adapted to expected new climate conditions, and assisted natural regeneration of functional species (FAO 2010). These issues have become increasingly critical as habitats and bioclimes have changed under the assault of climate change induced global warming. 
This is done to show how efforts to better integrate forest management and biodiversity protection efforts in the face of climate change resolve challenges both within and across sectors and also vertically across jurisdictional levels (McDermott et al 2009).

\section{The Historical Institutionalist Approach to Public Policy: Policy Legacies and the Need to}

\section{Examine Policy Integration Over Time}

Historical institutionalism is an approach used by policy scholars that emphasizes how public policies emerge from and are embedded in concrete temporal processes which constitute "institutions" (Thelen 2004). That is, in this approach, history and the sequencing of policy efforts matters more to policy formation than such commonly analyzed factor as the distribution of bargaining powers or the institutional reproduction of standard operating procedures (Knill and Tosun 2012).

Central to historical institutional analysis is the notion of path dependence in which later events in sequences or trajectories of policy efforts are heavily influenced by previous efforts or "policy legacies". Policy and institutional change it is argued typically occurs through a gradual process in which relatively/small changes are layered on top of earlier efforts and only in rare "critical junctures" lead to alterations in established trajectories.

But what is it that is changing, or remaining stable, in such policy sequences? The components of any policy regime can be represented as a two-dimensional structure (Table 1) composed of a number of distinct elements, namely combinations of policy goals and means existing across the levels of ideas, instruments and on-the-ground policy settings (Howlett, 2009; Kern and Howlett, 2009; Cashore and Howlett, 2007).

Table 1 - Taxonomy of policy elements (adapted from Kern and Howlett 2009)

\section{Policy Content}




\begin{tabular}{|c|c|c|c|c|}
\hline & & $\begin{array}{l}\text { High Level } \\
\text { Abstraction }\end{array}$ & $\begin{array}{l}\text { Program Level } \\
\text { Operationalization }\end{array}$ & $\begin{array}{l}\text { Specific On-the- } \\
\text { Ground Measures }\end{array}$ \\
\hline $\begin{array}{l}\text { Policy } \\
\text { Focus }\end{array}$ & $\begin{array}{l}\text { Policy } \\
\text { Ends or } \\
\text { Aims }\end{array}$ & $\begin{array}{l}\text { GOALS } \\
\text { What General } \\
\text { Ideas Govern } \\
\text { Policy } \\
\text { Development? }\end{array}$ & $\begin{array}{l}\text { OBJECTIVES } \\
\text { What Does Policy } \\
\text { Formally Aim to } \\
\text { Achieve? }\end{array}$ & $\begin{array}{l}\text { SETTINGS } \\
\text { What are the } \\
\text { Specific } \\
\text { On-the-ground } \\
\text { Requirements of the } \\
\text { Instruments }\end{array}$ \\
\hline ? & $\begin{array}{l}\text { Policy } \\
\text { Means or } \\
\text { Instruments }\end{array}$ & $\begin{array}{l}\text { LOGIC } \\
\text { What General } \\
\text { Norms Guide } \\
\text { Implementation } \\
\text { Preferences? }\end{array}$ & $\begin{array}{l}\text { MECHANISMS } \\
\text { What Specific } \\
\text { Policy } \\
\text { Instruments are } \\
\text { Used? }\end{array}$ & $\begin{array}{l}\text { CALIBRATIONS } \\
\text { What are the } \\
\text { Specific } \\
\text { Ways in Which the } \\
\text { Instrument is Used? }\end{array}$ \\
\hline
\end{tabular}

This framework suggests that policy changes can be analyzed by focusing on the evolving relationships existing within and between the six elements in the figure's cells over time. This is true in general, but also in terms of the measurement of the degree of integration found in a regime. Kern and Howlett (2009), for example, have argued that three relationships - coherence, consistency, and congruence - between these elements are important in assessing the extent of integration found in any sector.

Policy coherence is found where goals are tightly linked to the choice of objectives and the implementation norms often found in the program settings and calibrations. Incoherence occurs where there are contradictions between these elements. The addition of new goals or objectives always increases the risk of incoherence, as does the introduction of policy instruments that suppose new kinds of implementation preferences; for example, when a market orientation is introduced into an instrument set 
that has been based on a regulatory approach. Policy means are consistent when they work towards the same policy outcome Inconsistencies arise where the means work at cross-purposes, "providing simultaneous incentives and disincentives towards the attainment of stated goals" (Kern and Howlett, 2009: 6). Finally, policy congruence occurs when a consistent set of policy instruments supports a coherent set of goals. (Strambo et al 2015).

It is also the case that policy-making increasingly requires additional levels of integration both horizontally across sectors and vertically across levels of government. Thus achieving a high level of cross-sectoral integration in such circumstances involves the alteration of specific elements of existing policy 'mixes' or 'regimes' - the goals, objectives and calibrations of existing policy tools - across multiple sectors of government activity in order to produce a new policy mix, while avoiding the counterproductive or sub-optimal policy outcomes associated incoherence, inconsistencies and incongruence (Howlett and Rayner 2007).

\section{Impediments to Integration}

In a perfect world, balancing the sectoral, cross-sectoral and multi-level governance issues to provide a fully integrated policy regime would occur naturally in a seamless response to an obvious need, such as climate change in the case of forestry. However in practice this is rarely if ever the case. Enhancing integration rather requires significant management and careful calibration of policy tools and goals, policy processes, content and practices which can be very difficult to achieve and which, more significantly gets progressively more difficult to achieve given the creation of extensive path dependencies and policy legacies in any policy regime. That is, a key reason why integration is so difficult to achieve, is less related to factors such as a lack of desire or 
knowledge on the part of policymakers which would allow it to happen, but rather due to the fact that policy redesigns to promote congruence and enhanced integration of policy elements are typically undertaken in a context of uncertain futures and a history of past actions which embed or institutionalize previous policy goals and means, making them very difficult to change. These temporal or historical circumstances circumscribe policymakers' ability to act and constrain the range of options which they can pursue at any given moment in time (Howlett 2014; Briassoulis 2005a), including enhanced integration even in the face of such serious problems as climate change.

\section{Case Study: Assisted Tree Migration}

The difficulties in achieving integration and the central role played in them by policy legacies can be illustrated by the situation surrounding enhanced or assisted tree migration efforts in North America. These efforts require a high level of multi-sectoral and multi-level integration in order to overcome what Aitken et al (2008) termed 'adaptation lag,' which occurs when populations of organisms survive by maintaining a steady rate of adaptation, as most do.

As Johnston (2009) argued "if climate events last too long, become too frequent, or increase in intensity, an individual tree's ability to tolerate them will be exceeded and mortality will result". That is, as long as the rate of change in their environment is below a critical threshold determined by the "standing genetic variation, individual fecundity, effective population size, environmental stochasticity, and strength of selection," the species can adapt. Above this threshold, however, the rate of adaptation fails to keep pace with the rate of change in the environment and absolute fitness decreases with increasing adaptation lag, eventually causing not only individual mortality, but species extinction.

In Canada and the United States, the concern about on-the-ground climate change impacts such as increasing numbers of forest fires and insect damage on the forest sector has led 
to a focus on enhancing tree species and stands' adaptation abilities in the face of such changes.

This is in order to protect the continent's extensive forests, and the livelihoods of the communities that depend upon them, from adaptation lags in tree species affected by climate change (Lempriere et al 2008).

One such effort has centered on altering the species composition of existing forests in order to develop stands which are better able to accommodate the changing temperatures, insect and disease prevalence and type, and other similar impacts of global warming, including susceptibility to drought and fire damage. There are numerous ethical, social, economic and others concerns raised by the prospect of altering the species composition of forests, moving populations of native tree species either within or outside their historical range, or translocating non-native species into areas in which they have never occurred naturally (Aubin et al 2011). Nevertheless ATM, or the "intentional act of moving species, populations, or genotypes (the target) for the purpose of maintaining biological diversity or ecosystem functioning", has been frequently raised as an effective adaptation strategy for dealing with this aspect of climate change and global warming (Pedlar et al,, 2012; Klenk and Larson 2015). O’Neil et al (2008), for example, have advocated proactive interyention through assisted migration of seeds during plantation establishment "in order to maintain optimum forest health and productivity and to ensure capture of gains obtained from selective breeding" (p.1). Such management, it has been argued, is required due to the mismatch in rates of change between climate change and tree adaptation (Williams and Dumroese 2013; Schwartz et al 2012).

But attaining this goal is difficult. It requires better integration not only of traditional elements of the forest sector from tree-planters and nurseries to loggers and forest companies, but also better linkages with parks and wilderness advocates, conservationists, and industries like tourism and recreational fishing, as well as wildlife managers and hunters and elements of the agricultural and ranching communities who are all affected by forest composition changes. These efforts in turn occur and affect lands and practices at the state and provincial levels as well as the 
national, creating a multi-level integration challenge as well as a multi- or cross-sectoral one.

Successful restoration activities, beyond forest management objectives, use species and populations that are adapted to current and likely future conditions to successfully "reestablish resilient ecosystems after disturbances" (Vose 2012). In the eastern U.S., however, some species of trees have already shifted their distributions (northward) in response to changes in climate (Johnson et al 2013). One concern raised by those throughout the forest sector, therefore, is that global warming is occurring at a rate so much faster than normal, and climate shifts and freezing and other limits are moving at such a speed, that trees will not be able to migrate naturally (Leech et al 2011) given the longer time periods involved in such activity. Lempriere et al (2008), for example, found that in Canada "climate change may move isotherms (lines of equal temperature) northward by about $300 \mathrm{~km}$ within the next 50 years ... if annual mean temperature increases by $2{ }^{\circ} \mathrm{C}$, with a corresponding northward move of climate-dependent suitability zones for tree species" (p.17) This would outstrip the most optimistic estimates of the migratory ability of tree species.

Without considering ATM measures, the impacts of climate change are likely to lead to the possibility of maladaptation, increased disturbance, and other negative impacts on forest growth and composition. In addition to consequences for commercial forest management, ex situ conservation is part of broader biological conservation policy goals, and requires enhanced crosssectoral and multi-level co-ordination of policy efforts. As, Gauthier et al (2014) state, tree species management is part of larger strategy that addresses both forest resilience (the alteration of plant and animal distributions) and the changes in goods and services provided by forest ecosystems (the vulnerability occurring when populations or species are no longer suited to site conditions). That is, successful ATM necessitates a broad-based, integrative, approach to the subject.

Despite its promise to help resolve this issue, however, in nearly all jurisdictions ATM this integration has not occurred and ATM has yet to emerge as a viable forestry-climate change 
adaptive management option. Currently, where it is practiced, assisted migration focuses on preservation and habitat improvement, rather than ecological resilience and concerns for climate change adaptive capacity. Although this is changing in US federal forests, on-the-ground activities of the US Forest Service have yet to be affected. A US Forest Service report, for example, recently examined "current climate change knowledge and potential implications for forest tree species, as well as goals, principles, and recommendations for enhancing forest resilience and resistance through a re-aligned "climate-smart" National Forest System (NFS)" (Erickson et al 2012) but no amendments to policies were made or advocated on its basis.

In Canada, the situation has been similar; all provincial and territorial jurisdictions' forest management action is regulated by large omnibus Acts that define not only current regulations but also provide guidelines or explicit limits to the government's ability to enact a host of other different types of policy instruments. For example, Acts may include provisions for the establishment of a tree seed facility or the establishment of public ATM advisory groups or contain a moratorium on the use of genetically engineered stocks.

\section{ATM Practice to Date}

Several examples of ATM related on-the-ground calibrations of policy instruments nevertheless can be found within the major policy acts in Canada and the US (Table 2). They typically fall into three categories: the identification of more suitable genotypes through provenance trials, the modification of seed transfer zones, and the planting of alternate genotype or new species.

Two provinces (Newfoundland \& Labrador and New Brunswick) do not have any ATM related policy measures, whereas other provinces have less detailed ATM provisions such the Manitoba Conservation Forest Practices Guidebook: Protection Of Softwood Understory, which outlines only how to conserve and maintain tree genetics and species diversity. Significantly, these well established forest management-based calibrations have only changed in an incremental fashion within the sector in response to ATM efforts. 
Table 2: Assisted Tree Migration Policy Calibrations in Canada and the US

\begin{tabular}{|c|c|}
\hline Juri & Policy Calibration Examples \\
\hline $\begin{array}{l}\text { US Forest } \\
\text { Service }\end{array}$ & $\begin{array}{l}\text { Reforestation Policy Forest Service Manual, Genetic Resources } \\
\text { Management Forest Service Manual, Native Plant Material Policy Forest } \\
\text { Service Manual }\end{array}$ \\
\hline $\begin{array}{l}\text { Idland } \\
\text { rador }\end{array}$ & None \\
\hline \multirow[t]{2}{*}{$\begin{array}{l}\text { Prince Edward } \\
\text { Island }\end{array}$} & $\begin{array}{l}\text { PEI Ecosystem-based Forest Management Standards Manu } \\
\text { Renewal Program Regulations, forest management manual }\end{array}$ \\
\hline & Forest Renewal Program Regulations \\
\hline New Brunswick & None \\
\hline Nova Scotia & $\begin{array}{l}2008 \text { Code of Forest Practice: Interim Guidelines For Crown Land; } \\
\text { 1989Wildlife Habitat and Watercourses Protection Regulations }\end{array}$ \\
\hline Quebec & $\begin{array}{l}\text { Guidelines attached to the objective on the protection of the habitat of } \\
\text { species at risk or vulnerable in forest area (2008); Forest Management } \\
\text { Manual; General Forest Management Plans 2007-2012; Regulation on } \\
\text { intervention standards in State forests; Forest planning manual, 4th edition; } \\
\text { Integrated resources and territory management guide (IRTG); Ecosystemic } \\
\text { management reference manual for Quebec forest. MODULE 1: } \\
\text { implementation approach. }\end{array}$ \\
\hline On & $\begin{array}{l}\text { Forest Management Guide for Conserving Biodiversity ; The Forest } \\
\text { Operations and Silviculture Manual; Regeneration Survey Manual for Ontario; } \\
\text { The Species and Stock Selection Manual; Forest Management Planning } \\
\text { Manual for Ontario's Crown Forests; Artificial regeneration of Ontario's } \\
\text { Forests-Species and stock selection Manual. }\end{array}$ \\
\hline Man & $\begin{array}{l}\text { Manitoba Conservation Forest Practices Guidebook: Protection Of Softwood } \\
\text { Understory; Manitoba Forest Regeneration Survey Manual 2010; Manitoba } \\
\text { Free to Grow Survey Manual 2010(E); Forest Management Guidelines for } \\
\text { Terrestrial Buffers; Manitoba's Submission Guidelines for Twenty Year } \\
\text { Forest Management Plans }\end{array}$ \\
\hline & $\begin{array}{l}\text { The Forest Resources Management Regulations, Forest Planning Manual, } \\
\text { Forest Operations Manual, Compliance Manual; Scaling Manual }\end{array}$ \\
\hline & $\begin{array}{l}\text { Reforestation Standard of Alberta, Alberta Forest Management Planning } \\
\text { Standard, Timber Supply Analysis (TSA) and Growth \& Yield (G\&Y), } \\
\text { Alberta Forest Genetic Resource Management and Conservation Standards } \\
\text { (FGRMS), Forest Resources Improvement Regulation, Alberta Timber } \\
\text { Harvest Planning and Operating Ground Rules Framework for Renewal, } \\
\text { Tree Cone, Seed and Vegetative Material Regulation }\end{array}$ \\
\hline $\begin{array}{l}\text { British } \\
\text { Columbia }\end{array}$ & $\begin{array}{l}\text { Forest Practices Code Guidebooks; Seed and Vegetative Material } \\
\text { Guidebook; Operational Seed Planning Reference; Chief Forester's Standard } \\
\text { for Seed Use; Forest Planning and Practices Regulations Woodlot Licence } \\
\text { Planning and Regulations }\end{array}$ \\
\hline & Forest Management Regulations, Commercial Timber Harves \\
\hline
\end{tabular}




\begin{tabular}{|l|l|}
\hline Territories & Operations Standard Operating Procedures Manual \\
\hline Yukon & $\begin{array}{l}\text { Forest Resources Regulations, Forest Management Plan for the Teslin Tlingit } \\
\text { Traditional Territory; Champagne and Aishihik Traditional Territory Strategic } \\
\text { Forest Management Plan; Integrated Landscape Plan for the Champagne and } \\
\text { Aishihik Traditional Territory }\end{array}$ \\
\hline Nunavut & None \\
\hline
\end{tabular}

As Table 2 shows, in the case of forest management practices on both sides of the border, many forestry agencies have policy instruments, particularly comprehensive regulations, in place which are dedicated to reforestation practices and also specify which species that can be replanted. These instruments generally restrict ATM activities, howeyer. Currently, tree species reforestation regulations generally allow planting only to be carried out within an existing species range in order to improve forest productivity and health but without fundamentally affecting the tree composition of forestlands.

In Canada only three revisions to policy calibrations have been made. In Alberta, seed transfer guidelines have extended current reforestation guidelines northward by $2^{\circ}$ latitude and upslope by $200 \mathrm{~m}$ (Williams and Dumroese 2013). In Quebec, Ste-Marie (2014) noted that seed transfer models that take climate change into account have been developed and are being used to determine the locations where seedlings produced from seeds grown in seed orchards can be planted for the best chances of survival and growth to maturity. British Columbia's Ministry of Forests, Lands and Natural Resource Operations also recently allowed seeds of most species in most regions to be planted $200 \mathrm{~m}$ higher in elevation (Ste-Marie 2014). However, these changes were not directly attributable to climate change related goals and amounted to very minor adjustments to the status quo with little impact or effect on forest policy integration across sectors or jurisdictions.

The only significant policy change attributable to climate change to date in either the US or Canada has been the much publicized amendment of the British Columbia's 'Chief Forester's Standards for Seed Use' which were developed to enable the movement of western larch (Larix 
occidentalis Nutt.) from southern to northern parts of the province in 2010 (Government of British Columbia 2010; Klenk and Larson 2014). These changes took place in concert with considerable research undertaken by the Future Forest Ecosystem Initiative (FFEI) that was established by the Province's Chief Forester..

As Leech et al (2011) argued "it is imperative to adapt our forest management practices to foster resilient ecosystems that continue to provide a range of goods and services, including timber, bioenergy, biodiversity, water, and cultural values. The urgency is heightened by the key role played by trees in mitigating climate change". However, he challenge for forest managers is thus how to accommodate ATM on the ground and enhance integration in a policy context - or policy legacy - geared to an earlier age of plantings focused on species and stand stability.

In this context, Klenk and Larson (2015) and Klenk (2015) have argued that the BC amendment, for example, is a signal of significant institutional change, which goes beyond tinkering with existing rules in the face of climate change and may show the path towards overcoming policy legacies and moving towards a more facilitative ATM policy environment. However, it is easy to overstate the magnitude of this one particular policy change as in itself it does not represent an effort which willenhance policy integration in this sphere. As Ying and Yanchuk's (2006) analysis of British Columbia's tree seed transfer guidelines notes, incremental changes will still only be possible because of many existing impediments to the enhanced coordination and integration required to achieve paradigmatic changes to existing policies preventing enhanced ATM activities.

Steenberg et al (2012)'s review of broader SFM Criteria and Indicators (C\&I) related to the new BC rules, for example, found "that there are no requirements for adaptation strategies in forest management plans, nor are there guidelines and sufficient experienced personnel to aid such activities" (p.692). This type of omission is troubling because in order to be successful ATM must involve a more systematic effort to move policy and practice beyond forest management alone. Better integrating tree species policies, and ATM in particular into existing policy regimes 
is required if goals such as promoting sustainable forest management, preserving biodiversity, and adapting to climate change are to be attained (Johnston 2009). Currently seed planning zones, reforestation standards and hydrologic and wildlife management guidelines are all designed for the old climate regime with only lipservice given to long-term climate change adaptation considerations. In part, this can be explained by the continued scientific uncertainty in the basic ecological understanding about the long-term risks and benefits of assisted migration (McLachlan et al 2006), however it is mainly a function of the strength of existing policy legacies, plans and procedures from earlier eras of forest management when species were able to adapt by themselves to slower moving eco-system variances, legacies which continue to channel and steer existing forest policy efforts.

\section{Discussion: Overcoming Policy Legacies as a Barrier to Integration Through Policy Patching}

As this case study of ATM efforts has shown, in order to achieve better policy integration, policy designs must re-align or de-align and replace enough elements of established regimes to allow new initiatives to flourish (Howlett and Rayner 2013; Howlett 2014).

Overcoming the contextual "stickiness" of earlier regime elements, is critical to the success of policy reform efforts (Keysar 2005; Saglie 2006). This applies as much to efforts to reform existing forests policies, such as ATM, in an integrated fashion as to any other policy sector and initiative.

The kinds of policy reform dynamics which create such legacies are very well known and research into policy areas such as health and welfare, and many others, has revealed that existing policy mixes typically emerge through one or more of four common long-term policy development processes: 'layering', 'drift', 'conversion', and 'replacement' (Beland, 2007; Thelen 2003 and 2004; Hacker 2004 and 2005; Stead and Meijers, 2004; Evers and Wintersberger 1990; Evers 2005; Briassoulis 2005). The basic aspects of each of these processes is set out in Table 3 below. 
Table 3 - Processes of Policy Change and Their Impact on Policy Integration

\begin{tabular}{|l|l|}
\hline Process & Description \\
\hline Layering & $\begin{array}{l}\text { When new elements are simply added to an existing regime without } \\
\text { abandoning previous ones, typically leading to both incoherence } \\
\text { amongst the goals and inconsistency with respect to the instruments } \\
\text { and settings used. }\end{array}$ \\
\hline Drift & $\begin{array}{l}\text { When the elements of a policy mix are deliberately maintained } \\
\text { while the policy environment changes. The impact of the policy } \\
\text { mix is thus likely to change and this is the result that the designer } \\
\text { wants to achieve (Hacker, 2004). }\end{array}$ \\
\hline Conversion & $\begin{array}{l}\text { Involves holding most of the elements of the policy mix constant } \\
\text { while redeploying the mix to serve new goals (van der Heijden } \\
\text { 2010). While consistency may remain largely intact, conversion } \\
\text { poses significant risks of incongruence between the old instrument } \\
\text { elements and the new goals that have been introduced. }\end{array}$ \\
\hline Replacement & $\begin{array}{l}\text { Replacement occurs when there is a conscious effort made to re- } \\
\text { create or fundamentally re-structure policies through the } \\
\text { replacement of old goals and means by new ones so that they both } \\
\text { become consistent, coherent and congruent. }\end{array}$ \\
\hline
\end{tabular}

Adapted from Wellstead et al (2016)

The first of these dynamics, 'layering', connotes a process in which new elements are

added to an existing regime without abandoning previous ones. Layering is especially

problematic for policy integration as incremental changes in the mixture of policy elements over a

decade or more can create a situation where the elements can fail to be mutually supportive,

incorporating contradictory goals or instruments whose combination create perverse incentives

that frustrate policy goals. That is, the consequence of layering mix elements over the long-term,

as Kay (2007) suggests, is usually tension between the layers. Repeated bouts of layering can lead

to both incoherence amongst the goals and inconsistency with respect to the instruments and

settings used in a policy area.

Drift occurs when new goals replace old ones without changing the instruments used to

implement them. These instruments then can become inconsistent with the new goals and most

likely ineffective in achieving them (Hacker 2004 and 2005; Torenvlied and Akkerman 2004). 
Conversion involves the reverse situation whereby new instrument mixes evolve while holding old goals constant. If the old goals lack coherence, then changes in policy instruments may either reduce levels of implementation conflicts or enhance them, but are unlikely to succeed in better matching the means and ends of policy (Thelen 2004).

Replacement occurs when there is a conscious effort made to re-create or fundamentally re-structure policies through the replacement of old goals and means by new ones so that they both become consistent, coherent and congruent (Eliadis, Hill and Howlett 2005; Gunningham and Sinclair 1999). While often the holy grail of many policy reformers, however, replacement assumes that existing policy elements can be more or less easily replaced by new ones and much longitudinal policy research has found few cases of wholesale regime replacement (Davenport et al 2007; Dimitrov 2002 and 2004).

Most existing policy regimes, especially in very old sectors such as forestry have developed haphazardly through processes of policy layering, or repeated bouts of policy conversion or policy drift, in which new instruments and objectives have been piled on top of older ones (Carter 2012). These disorganized policy mixes have been widely observed in many policy areas (Bode 2006; Butler 2009), including forestry, and pose a significant impediment to the achievement of a transition to a forest policy with better cross sectoral integration. This is the current situation faced by efforts to achieve and implement ATM.

This is very apparent in the ATM case where in most cases new ATM policy goals and instruments have simply been added to older replanting ones while in some jurisdictions efforts are being made to stretch existing arrangements into the new era, a strategy which is likely to fail. Due to existing policy legacies the adaptation of forests to climate change in this key policy area is likely to continue to feature incremental adjustments through policy layering and policy drift rather than involve wholesale policy replacement.

Compared to the rare wholesale "re-packaging" of elements which results in instances policy replacement, however, more limited forms of policy "tinkering” (Weimer 1993, van der 
Heijden 2011) such as "patching" (Howlett and Rayner 2013) or "stretching" (Feindt and Flynn 2009)are possible in which more limited efforts are made to alter or correct specific aspects of existing regimes in order to allow them to function effectively in new circumstances (Howlett and Rayner 2013).

New policy goals and instruments, for example, can be developed through the creation and implementation of carefully designed policy 'patches' (Howlett and Rayner 2013) which can bring additional elements to a mix in order to bolster existing elements, enhance integration and alter the direction or trajectory of policy-making.

Although patching can also be problematic as the addition of new goals or objectives always increases the risk of incoherence, and inconsistencies may also arise where the means work at cross-purposes, "providing simultaneous incentives and disincentives towards the attainment of stated goals" (Howlett and Rayner 2007; Kern and Howlett, 2009: 6), a phenomenon which often happens when existing aspects of policies are 'stretched' (Feindt and Flynn 2009) in order to cover areas they were not intended to address. Such stretching weakens the resilience of existing arrangements and leaves them vulnerable to failure in the event of further stresses (Beland, 2007; Thelen 2004; Hacker 2004; Hacker and Beland 2004; Stead and Meijers, 2004). However more intelligent or 'smart' patching in which interventions are carefully constructed so as to support or alter existing arrangements rather than just add another layer of tools and ends, or stretch existing ones, holds out more promise for enhanced policy integration in the face of new challenges.

These dynamics and processes of policy tinkering and policy repackaging are readily apparent in the ATM case. Johnston (2009) and Williams and Dumroese (2013) identify five key ATM management objectives: reforest managed forest land, conserve genetic diversity, maintain 
species productivity, maintain forest health. Efforts to attain these ends can proceed either through 'stretching' when no reforms are mooted, through layering or through patching (see

Figure 3). Only the later holds out any hope of significantly altering existing arrangements in the desired direction of better adaptation integrated across sectors and jurisdictions.

Figure 3. ATM tinkering versus repackaging

\begin{tabular}{|c|c|c|}
\hline $\begin{array}{l}\text { Policy } \\
\text { Objective }\end{array}$ & $\begin{array}{l}\text { Layering outcomes involving } \\
\text { tinkering dominated by } \\
\text { forest management goals }\end{array}$ & $\begin{array}{l}\text { Repackaging outcomes involving } \\
\text { Integrative goals (including climate } \\
\text { change and biodiversity) }\end{array}$ \\
\hline $\begin{array}{l}\text { Reforest } \\
\text { managed } \\
\text { forest land }\end{array}$ & $\begin{array}{l}\text { Assisted population expansion: } \\
\text { movement of populations within a } \\
\text { species' range to improve productivity } \\
\text { and health in new climates }\end{array}$ & $\begin{array}{l}\text { Translocation of exotics: inter-regional, } \\
\text { Transcontinental, or intercontinental } \\
\text { movement of species }\end{array}$ \\
\hline $\begin{array}{l}\text { Conserve } \\
\text { genetic } \\
\text { diversity }\end{array}$ & $\begin{array}{l}\text { Maintaining a diversity of age classes } \\
\text { and species where it does not increase } \\
\text { susceptibility to insects, disease, or fire } \\
\text { Thinning stands on drought-prone sites } \\
\text { to reduce water use where it will not } \\
\text { increase susceptibility to windthrow or } \\
\text { disease }\end{array}$ & $\begin{array}{l}\text { Favouring drought-tolerant species in } \\
\text { drought prone areas } \\
\text { Shortening rotation ages and } \\
\text { Controlling undesirable plant species that } \\
\text { are likely to become more competitive in a } \\
\text { changed climate. } \\
\text { Replanting with more robust genotypes } \\
\text { Corridors that facilitate the migrations of } \\
\text { tress species and genotypes and the } \\
\text { development of artificial reserves are two } \\
\text { examples }\end{array}$ \\
\hline $\begin{array}{l}\text { Maintain } \\
\text { species } \\
\text { productivity }\end{array}$ & $\begin{array}{l}\text { Using silvicultural systems that } \\
\text { maintain genetic and species diversity }\end{array}$ & $\begin{array}{l}\text { Creating and maintaining corridors that } \\
\text { facilitate the migration of tree species and } \\
\text { genotypes } \\
\text { Creating artificial reserves } \\
\text { Using ex situ collections to preserve rare } \\
\text { populations }\end{array}$ \\
\hline $\begin{array}{l}\text { Maintain } \\
\text { forest he }\end{array}$ & $\begin{array}{l}\text { Focusing harvest activities on stands } \\
\text { that are most susceptible to pests, or } \\
\text { conducting sanitation cutting in stands } \\
\text { that are already affected }\end{array}$ & $\begin{array}{l}\text { Developing genotypes that are drought } \\
\text { tolerant and resist insects and disease } \\
\text { Putting more effort into integrating climate } \\
\text { change models with biological models of } \\
\text { phenology. } \\
\text { Using prescribed burning to reduce fire } \\
\text { risk and forest vulnerability to insect } \\
\text { outbreaks }\end{array}$ \\
\hline
\end{tabular}

Based on Johnston (2009)

\section{Conclusion}


Camancio (2010) states that "assisted migration exemplifies how climate change necessitates the reinvention of natural resource management to better reflect and manage a dynamic world" (p.175). The paper presents a case study of ATM to show that while the impact of climate change has led many forest managers to advocate for the addition of ATM into forest management policies, little has been accomplished on the ground.

This paper addresses a gap in the climate change literature, namely explaining the ambiguity inherent in a complex policy-making environment subject to rapid enyironmental change (Wellstead et al 2013; Cairney et al 2016). The nuanced understanding of policy reform processes put forward here shows how effective adaptation policy can indeed" be responsive to a wide variety of economic, social, political, and environmental circumstances" (Spittlehouse and Stewart 2005), while also emphasizing the difficulties of so doing.

This discussion highlights the limitations imposed on policy change by policy legacies which both generate inconsistencies and incoherencies in existing policies and lead to policy tinkering in the effort to resolve them. Preyious rounds of domestic policymaking have constrained needed policy change in this area, preventing larger-scale more integrated efforts at policy development.

But climate change is not going away anytime soon. The pressures of global warming and broader climate change policy agendas will inevitability lead on-the-ground policy and programs changes within the forest sector, particularly when addressing the critical issue of species conseryation. Although attaining a fully integrative ATM policy requires changes in the current US and Canadian forest policy regimes, these regimes are riddled with policy legacies and path dependencies meaning full replacement is highly unlikely. At best, climate change based ATM policy considerations in the forest sector will involve more subtle processes of policy patching. Nevertheless efforts must be made in this direction if positive results are to follow from 
efforts to reform forest policies to deal effectively with contemporary issues such as climate change induced warming.

Such reform may come from outside of ossified existing policy regimes, through various kinds of bottom-up and top-down policy leadership. An example of the former, for example, occurred in Florida recently in the actions of the Torreya Guardians group which, for nearly a decade, has taken a variety of assisted migration actions to protect the endangered Torreya taxifolia. Motivated by climate change impacts and possible extinction of this conifer species, this group of botanists and amateur enthusiasts outpaced forest services in planting seedlings 400 miles north of the torreya's current natural range to sites in the North Carolina mountains (Economist 2015). Similarly, in what could portend an important development in this area, for example, the Forest Products Association of Canada (FPAC) stated that assisted migration of tree species is an important approach to "adapting our sustainable forest management to climate change" (FPAC 2016).

Such citizen and industry-led science and advocacy may provide a vehicle for policy patching in the face of stymied top-down policy dynamics and provide an additional avenue to reform and enhanced integration in the sector (Howlett and Rayner 2001).

\section{References}

Aitken SN, Yeaman S, Holliday JA, Wang T, Curtis-McLane S, 2008. Adaptation, migration or extirpation: climate change outcomes for tree populations. Evolutionary Applications 1(1): 95-111.

Aubin I, Garbe CM, Colombo S, Drever CR, McKenney DW, Messier C, Pedlar J, Saner, MA, Venier L, Wellstead AM, Winder R. 2011. Why we disagree about assisted migration 1: Ethical implications of a key debate regarding the future of Canada's forests. The Forestry Chronicle. 87(6):755-765.

Backman F, Mårald E. 2016. Is there a Nordic Model for the treatment of introduced tree species? A comparison of the use, policy, and debate concerningintroduced tree species in the Nordic countries Scandinavian Journal of Forest Research. 31(2): 222-232

Beland D, 2007.Ideas and institutional change in social security: Conversion, layering and policy drift. Social Science Quarterly. 88(1): 20-38.

Bode I. 2006. Disorganized welfare mixes: Voluntary agencies and new governance regimes in Western Europe. Journal of European Social Policy. 16(4): 346-359. 
Briassoulis H, 2005. Analysis of policy integration: Conceptual and methodological considerations. In Policy Integration for Complex Environmental Problems: The Example of Mediterranean Desertification. Aldershot: Ashgate,

Butler S, 2009. Obstacles to the implementation of an integrated national alcohol policy in Ireland: Nannies, Neo-Liberals and joined-up government. Journal of Social Policy. 38:2 343-359.

Cairney P, Oliver K, Wellstead A, 2016. To bridge the divide between evidence and policy: Reduce ambiguity as much as uncertainty. Public Administration Review, 76: 399-402.

Camacho AE 2010. Redefining nature and natural resource law under climate change. University of California, Irvine School of Law; Notre Dame Law School. Legal Studies Research Paper No. 2009-37.

Carter P, 2012. Policy as palimpsest. Policy \& Politics 40(3): 423-443.

Cashore B, Howlett M, 2007. Punctuating which equilibrium? Understanding thermostatic policy dynamics in Pacific Northwest forestry. American Journal of Political Science. 51(3):53251.

Dimitrov RS, 2002. Confronting nonregimes: science and international coral reef policy. The Journal of Environment Development 11(1): 53-78.

Dimitrov R, Sprinz D, DiGiusto G, Kelle A, 2007. International nonregimes: A research agenda. The International Studies Review 9: 230-258.

Dimitrov R, 2004. Lost in the woods: International forest policy. In: Science and Politics in the International Environment. Harrison N, Bryner G. 173-202. New York: Rowman and Littlefield Publishers.

Economist, 2015. A Modern Ark: To save endangered species move them to more congenial places. November $28^{\text {th }}$.

Eliadis P, Hill M, Howlett, M eds, 2005. Designing government: from instruments to governance. Montreal: McGill-Queen's University Press.

Erickson V, Aubry C, Berrang P, Blush T, Bower A, Crane B, DeSpain T, Gwaze D, Hamlin J, Horning M, Johnson R, et al. 2012. Genetic resource management and climate change: genetic options for adapting national forests to climate change. US Forest Service.

Evers A, 2005. Mixed welfare systems and hybrid organizations: changes in the governance and provision of social services. International Journal of Public Administration. 28: 737-748.

Evers A, Wintersberger H, 1990. Shifts in the welfare mix: Their impact on work, social services and welfare policies. Frankfurt/Boulder: Campus/Westview

Feindt PH, Flynn, A, 2009. Policy stretching and institutional layering: British food policy between seeurity, safety, quality, health and climate change. British Politics 4(3): 386-414.

Forest Products Association of Canada (FPAC), 2016. Climate change and Canada's forests. http://www.fpac.ca/wp-content/uploads/ClimateChange_April2015.pdf

Gauthier S, Bernier P, Burton PJ, Edwards J, Isaac K, Isabel N, Jayen K, Le Goff H, Nelson EA, 2014. Climate change vulnerability and adaptation in the managed Canadian boreal forest 1 . Environmental Reviews. 22(3):256-85.

Government of British Columbia, 2010. Assisted Range and Population Expansion of Western Larch for Use as a Climate Change Adaptation Strategy in British Columbia - June 2010. https://www.for.gov.bc.ca/ftp/hti/external/!publish/Western_Larch_Interim_Measures_2010/ INTERIM_Lw_Review_Package_FINAL.pdf

Guisan A, Tingley R, Baumgartner JB, Naujokaitis- Lewis I, Sutcliffe PR, Tulloch AI, Regan TJ, Brotons L, McDonald- Madden E, Mantyka- Pringle C, Martin TG. Predicting species distributions for conservation decisions, 2013. Ecology letters. 16(12):1424-35.

Gunningham N,,Sinclair D, 1999. Regulatory pluralism: Designing policy mixes for environmental protection. law and policy. 21(1): 49-76. 
Hacker JS, 2005. Policy drift: The hidden politics of US welfare state retrenchment In Beyond Continuity: Institutional Change in Advanced Political Economies, edited by W. Streek and K. Thelen, 40-82. Oxford: Oxford University Press, 2005.

Hacker JS, 2004. Review article: Dismantling the health care state? Political institutions, public policies and the comparative politics of health reform. British Journal of Political Science. 34: 693-724.

Howlett M, Rayner J, 2007. Design principles for policy mixes: Cohesion and coherence in 'New Governance Arrangements'. Policy and Society 26(4): 1-18.

Howlett M, Rayner, J, 2007. Design Principles for Policy Mixes: Cohesion and Coherence in 'New Governance Arrangements'. Policy and Society 26(4): 1-18.

Howlett M, 2014. From the 'old'to the 'new'policy design: design thinking beyond markets and collaborative governance. Policy Sciences. 47(3):187-207.

Howlett M, 2009. Governance modes, policy regimes and operational plans: A multi-level nested model of policy instrument choice and policy design. Policy Sciences. 42(1):73-89.

Howlett M, Rayner J, 2013, Patching Vs Packaging in Policy Formulation: Assessing Policy Portfolio Design. Politics and Governance. 1(2): 170-182.

Howlett M, Rayner J, 2001.The business and government nexus: principal elements and dynamics of the Canadian forest policy regime. Canadian forest policy: Adapting to change. 23-64.

Howlett M, Rayner J, Goehler D, Heidbreder E, Perron-WelchF, Rukundo/O, Verkooijen P, Wildburger C. Overcoming the challenges to integration: Embracing complexity in forest policy design through multi-level governance. 2011. In Embracing complexity: meeting the challenges of international forest governance: A global assessment report prepared by the Global Forest Expert Panel on the International Forest Regime, Rayner R, Buck, A, Katila P. 93-110. IUFRO World Series No. 28. Vienna: International Union of Forest Research Organizations, 2011.

Howlett M, 2014. Policy design: What, who, how and why? In L'instrumentation et Ses Effets, Halpern, C., Lascoumes, P., and Le Galès P., eds. Paris: Paris, Presses de Sciences Po..

Johnson R, Boyce S, Brandt L, Erickson V, Iverson L, Kujawa G, Tkacz, B, 2013. Policy and strategy considerations for assisted migration on USDA Forest Service lands. In: Browning, J.; Palacios, P., comps. Proceedings of the 60th Annual Western International Forest Disease Work Conference; 2012 October 8-12; Tahoe City, CA. [place of publication unknown]: Western International Forest Disease Work Conference: 35-41.

Johnston M, 2009. Vulnerability of Canada's tree species to climate change and management options for adaptation: an overview for policy makers and practitioners. Canadian Council of Forest Ministers.

Kay A, 2007. Tense layering and synthetic policy paradigms: The politics of health insurance in Australia. Australian Journal of Political Science. 42(4):579-91.

Klenk NL, The development of assisted migration policy in Canada: An analysis of the politics of composing future forests. Land Use Policy. 2015 Mar 31;44:101-9.

Klenk NL, Larson BM. 2015. The assisted migration of western larch in British Columbia: A signal of institutional change in forestry in Canada?. Global Environmental Change. 31:207.

Kern F, Howlett M, Implementing transition management as policy reforms: a case study of the Dutch energy sector. 2009. Policy Sciences. 42(4):391-408.

Keysar E, 2005. Procedural integration in support of environmental policy objectives: Implementing sustainability." J.Environ.Plann.Manage. 48(4): 549-569.

Kjær WD, Lobo A, Myking, T, 2014. The role of exotic tree species in Nordic forestry. Scandinavian Journal of Forest Research. 29(4): 323-332.

Knill, C. and Tosun, J, 2012. Public policy: A new introduction. London: Palgrave Macmillan.

Leech SM, Almuedo PL, O'Neill G, 2011. Assisted migration: adapting forest management to a changing climate. Journal of Ecosystems and Management. 12(3). 
Lemprière TC, Bernier PY, Carroll AL, Flannigan MD, Gilsenan, RP, McKenney DW, Hogg EH, Pedlar JH, Blain D, 2008. The importance of forest sector adaptation to climate change. Nat. Resour. Can., Can. For. Serv., North. For. Cent., Edmonton, AB. Inf. Rep. NOR-X-416E.

McLachlan JS, Hellmann JJ, Schwartz MW, 2006. A framework for debate of assisted migration in an era of climate change. Conservation Biology, 21(2):297-302.

O’Neill GA, Ukrainetz NK, Carlson MR, Cartwright CV, Jaquish BC, King JN, Krakowski J, Russell JH, Stoehr MU, Xie C, Yanchuk AD, 2008. Assisted migration to address climate change in British Columbia: recommendations for interim seed transfer standards. B.C. Min. For. Range, Res. Br., Victoria, B.C. Tech. Rep. 048. www.for.gov.bc.ca/hfd/pubs/Docs/Tr/Tr048.htm

Pedlar JH, McKenney DW, Aubin I, Beardmore T, Beaulieu J, Iverson L, O'Neill GA, Winder RS, Ste-Marie C, 2012. Placing forestry in the assisted migration debate. BioScience. 62(9):835-42.

Saglie IL, 2006. Fragmented institutions: the problem facing natural resource management. Network and institutions in natural resources management. Cheltenham, Edward Elgar.

Schwartz MW, Hellmann JJ, McLachlan JM, Sax DF, Borevitz JO, Brennan J, Camacho AE, Ceballos G, Clark JR, Doremus H, Early R, 2012. Managed relocation: integrating the scientific, regulatory, and ethical challenges. BioScience. 62(8):732-43.

Spittlehouse D L, Stewart R, 2004. Adaptation to climate change in forest management. Journal of Ecosystems and Management 4(1)

Stead, D, Geerlings H, Meijers, K, 2004. Policy Integration in Practice: The Integration of Land Use Planning, Transport and Environmental Policy-Making in Denmark, England and Germany. Delft: Delft University Press.

Ste-Marie,C, 2014. Adapting sustainable forest management to climate change:a review of assisted tree migration and its potential role in adapting sustainable forest management to climate change. Can. Counc. For. Minist., Ottawa, ON.

Steenberg J W, Duinker P N, Van Damme, L, Zielke K, 2012. Criteria and indicators of sustainable forest management in a changing climate: an evaluation of Canada's national framework. Journal of Sustainable Development, 6(1): 32-64.

Strambo C, Nilsson M, Månsson A, 2015. Coherent or inconsistent? Assessing energy security and climate policy interaction within the European Union. Energy Research \& Social Science. 8:1-12.

Thelen K, 2003. How Institutions Evolve: Insights from Comparative Historical Analysis. In Comparative Historical Analysis in the Social Sciences, Mahoney J, Rueschemeyer, D. 208-240. Cambridge: Cambridge University Press.

Thelen K, 2004. How Institutions Evolve: The Political Economy of Skills in Germany, Britain, the United States and Japan. Cambridge: Cambridge University Press.

Torenvlied R, Akkerman A. 2004. Theory of 'soft'policy implementation in multilevel systems with an application to social partnership in the Netherlands. Acta Politica. 39(1):31-58.

Van der Heijden J, 2011. Institutional Layering: A Review of the Use of the Concept. Politics 31(1): 9-18.

Vose JM, Peterson DL, Patel-Weynand T, Effects of climatic variability and change on forest ecosystems: a comprehensive science synthesis for the US. Gen. Tech. Rep. PNW-GTR870. Portland, OR: U.S. Department of Agriculture, Forest Service, Pacific Northwest Research Station. 265 p.

Weimer DL, 1993. The current state of design craft: Borrowing, tinkering, and problem solving. Public Administration Review 53(2): 110-20.

Wellstead A, Howlett M,Rayner J, 2013. The neglect of governance in forest sector vulnerability assessments: structural-Functionalism and 'Black Box' Problems in Climate Change Adaptation Planning. Ecology and Society. 18(3): 23. 
Wellstead A, Rayner J, Howlett M, 2016. Alberta's oil sands reclamation policy trajectory: the role of tense layering, policy stretching, and policy patching in long-term policy dynamics. Journal of Environmental Planning and Management. 1-18.

Williams MI, Dumroese RK, 2013. Preparing for climate change: Forestry and assisted migration. Journal of Forestry. 111(4): 287-297.

Ying CC, Yanchuk AD, 2006. The development of British Columbia's tree seed transfer guidelines: purpose, concept, methodology, and implementation. Forest Ecology and Management. 227(1):1-13. 